\title{
Living in Patchy Habitats: Substrate Selection for Basking by Sympatric Lizards in Contrasted Anthropogenic Habitats in Western France
}

\section{Roger Meek}

IDECC

Luca Luiselli ( $\square$ lucamaria.luiselli@uniroma3.it )

Rivers State University of Science and Technology https://orcid.org/0000-0001-6878-2916

\section{Research Article}

Keywords: urban lizards, basking, substrate selection

Posted Date: November 8th, 2021

DOl: https://doi.org/10.21203/rs.3.rs-300197/v1

License: (c) (1) This work is licensed under a Creative Commons Attribution 4.0 International License.

Read Full License 


\section{Abstract}

The influence of temperature on the physiological processes in reptiles is well known, for example growth, reproduction, muscular energy are all largely temperature dependent and therefore temperature is a key aspect of reptilian ecology. However, there may be constraints on the ability of reptiles to harness thermal energy, particularly during cold seasons in the temperate zones. Substrate selection is a key aspect in thermoregulation and can enhance heat uptake. For example, wood substrates are known to increase rates of heat gain in basking reptiles enabling earlier attainment of optimum body temperatures compared to other substrate types, which enables increased time available for other activities. In this paper we describe substrate use for basking in two species of lizard, Lacerta bilineata and Podarcis muralis in a hedgerow and suburban garden in western France compared against a null model of substrate availability. When different substrates were pooled based on their material similarities both species were recorded in greater frequency on wood based materials in comparison to their availability compared to non-wood substrates. However at a finer level, in comparison to substrate availability (fallen tree branches, tree stumps, open ground etc), P. muralis showed strong substrate selection for basking, whereas $L$. bilineata did not depart significantly from the null model. We speculated that intra-specific aggression in L. bilineata was a possible cause of this result due to dominant individuals limiting smaller or female lizards from accessing prime basking sites. Differences in communal basking between the two species supported this notion.

\section{Introduction}

The expansion of urban areas and modification to natural environments by agriculture is a key cause of reptile population declines (e.g. Jellinek et al. 2004; Audsley et al. 2006; Böhm et al. 2013; Keinath et al. 2016). Major changes to vegetation structure may impact upon a reptiles eco-physiological performance (Keinath et al. 2016; Yang Hu et al. 2020). For example, reptile body temperature levels determine whether they can perform at optimum physiological levels and this in turn depends on the thermal quality of the substrates (Huey and Slatkin 1976; Huey, 1991; Castilla et al. 1999). Adaptation therefore requires a habitat offering a suitable thermal environment with basking opportunities to raise body temperatures and also access to shaded areas for cooling (e.g., Avery 1979; Basson et al. 2019). The costs of moving to and from optimum basking areas in terms of both energy costs and predation risk during movement should be lower than the benefits gained (Huey and Slatkin, 1976; Huey 1991). Abundance of both prey and retreat sites is also critical and hence reptiles are constrained to balance these factors, which will have different ratios of cost-benefits depending on the quality of the habitat (Carrascal et al. 1992; Herczeg et al. 2008; Basson et al. 2017). Therefore, population persistence in altered habitats, including patchy habitat and suburban areas is subject to the same thermal and other ecological constraints/requirements.

Lacertid lizards regulate body temperatures by selecting thermally favourable microhabitats (via appropriate substrates) and adjusting activity times and behaviour that alter heat exchange with the environment (e.g., Bauwens et al. 1996; Castilla et al. 1999). Two of the most common lacertids in 
Western Europe, the wall lizard (Podarcis muralis) and the green lizard (Lacerta bilineata), occur in a wide range of environments that include suburban gardens and agricultural areas (e.g. Corti et al. 2011; Speybroeck et al. 2016). Both are lacertid lizards that differ substantially in terms of body size ( $L$. bilineata being much larger; see Corti et al. 2011), primarily consume a range of insects (Barbault and Mou 1986; Angelici et al. 1997; Speybroeck et al. 2016) and $P$. muralis is essentially an active forager whilst Lacerta bilineata is a sentinel predator (Verwaijen and Van Damme 2008). Body temperatures of up to around $36^{\circ} \mathrm{C}$ have been recorded by $P$. muralis in the field (Avery 1978; Bauwens al. 1995) with $L$. bilineata $\left(=\right.$ L. viridis) around $34^{\circ} \mathrm{C}$ (e.g. Rismiller and Heldmaier 1988). The success of these lizards in anthropogenic environments is therefore of particular interest because of (i) their contrasted life-histories and (ii) the highly modified landscapes they inhabit typically impact on physical structure, micro-climates and the species composition of natural vegetation, thus potentially isolating populations (e.g. Germaine and Wakeling 2001). For example, agricultural mono-cultures have little value to most wildlife and the remaining usable habitat in such landscapes is often hedgerow systems (Saint Girons 1996; Luiselli and Capizzi 1997). Hedgerows are typically linear habitats that may be used as permanent home ranges for some species, whilst for others they function as connection pathways to more usable habitats (Saint Girons 1996; Vignoli et al. 2009; Meek, 2014a 2014b; Rugerio et al. 2018). Suburban gardens are also typically highly altered in structure compared to natural habitats but many species of lizard, especially $P$. muralis, are capable of adapting to these anthropogenic environments including having the ability to colonize completely new areas (e.g. Allan et al. 2006; Mole 2010; Corti et al. 2011; Heym et al. 2013). Evidence of anthropogenic impact on reptiles is perhaps the least understood of vertebrates (e.g. McCoid et al. 1994; Walker et al. 1996; Jellinek et al. 2004) and here we examine one aspect of how these two species of lizard utilize such habitats using data on substratum selection.

The size differences between $L$. bilineata and $P$. muralis is an important factor in their thermal biology impacting primarily on differences in rates of heating and cooling size (e.g. Corti et al. 2011). Indeed, $P$. muralis heats around 1.5 times faster than L. bilineata (e.g. Hailey 1982). Time spent basking could also be expected to impact on time budgets for other daily activities but microhabitat/substratum selection can also influence heating rates (e.g., Hailey 1982). For example, heat conduction from substrates can be important during sunny weather but especially during cloudy weather (Avery 1979; Beebee and Griffiths 2020). In a study of basking substrates used by the cold adapted lacertid Zootoca vivipara, Hailey (1982) found that for basking wood surfaces were mostly selected during overcast or changeable weather compared to grass but there was non-selection of wood during sunny days. This was attributed to the costs (energy costs of movement, risk of predation) of moving to a warm substrate for basking during sunny weather compared to the benefits of more rapid body temperature increases from using wood substrates (Hailey 1982).

The present study was prompted by observations of basking behaviour and substratum selection by lizards in two contrasted anthropogenic habitats in west France: (i) a hedgerow with sympatric $L$. bilineata and $P$. muralis, and (ii) a suburban garden, situated at a relatively short distance $(0.9 \mathrm{~km})$ from the above-mentioned hedgerow, where only a $P$. muralis population is found. Because of the close vicinity 
of these habitats, the climate was nearly identical (and thus comparable) between areas but the vegetation structure and the ecological conditions were very different. Hailey's (1982) study was undertaken in the cooler climate of the south of England, approximately $650 \mathrm{~km}$ north of our study area, where temperatures are lower with also greater cloud cover and fewer sunshine hours. We therefore posed a general question of whether substratum selection for basking would have equal importance in more southerly species. Specifically we attempted to answer the following questions:

1) Are there any species-specific preferences for substratum selection in basking wall and green lizards in the hedgerow? We ask this question because the substratum and perching materials available to the lizards in diverse habitats may differ in specific heat capacity. For example, wood in general is around $1.17 \mathrm{~J} / \mathrm{g}^{\circ} \mathrm{C}$, Ash wood very similar at $1.6 \mathrm{~J} / \mathrm{g}^{\circ} \mathrm{C}$, concrete $0.88 \mathrm{~J} / \mathrm{g}^{\circ} \mathrm{C}$ and limestone $0.75 \mathrm{~J} / \mathrm{g}^{\circ} \mathrm{C}$. Therefore in a theoretical low cost thermal environment, lizards should select substrates for basking that represent low cost in terms of rates of heat gain if the costs of reaching or using them outweigh the risks. In this study the presence of trees and fallen branches in the hedgerow and also deadwood in the garden habitat were within reasonably short distance of each other (Fig. 1) and we predicted that wood-based materials should be selected for in terms of the advantages gained in heating rates in achieving optimum body temperature relation to their availability.

2) Do lizards adjust basking substrate selection with season and are there any differences in this respect between the two species? We ask this question because as summer progresses and the environment warms lizards may be less dependent on substrates offering greater heating rates. We therefore predicted that selection for the high $1.17 \mathrm{~J} / \mathrm{g}^{\circ} \mathrm{C}$ wood based substratum would decline.

3) Does communal basking occur in different species and if so is there a difference in frequency for this behaviour between $L$. bilineata and $P$. muralis? We ask this question because competition for prime basking sites may enhance thermoregulatory capability in some lizards if they can exclude potential competitors from optimum basking sites (e.g. Huey and Slatkin 1979).

\section{Methods}

\section{Study areas and protocol}

From March to October 2020, sympatric populations of $P$. muralis and Lacerta bilineata were studied in a hedgerow (PH) system on the edge of the village of Chasnais $\left(46^{\circ} 27^{`} \mathrm{~N} ; 1^{\circ} 53^{`} \mathrm{~W}\right)$, and a population of $P$. muralis in a urban garden in the same village in Western France until November 29 (Fig. 1). The garden area was $1197 \mathrm{~m}^{2}$. The hedgerow can also be described as a low cost thermal environment in the sense of Huey and Slatkin (1976) in that it is structurally relatively simple consisting of mostly low growing bush (Rubus fruticosus and Hedera helix) with open sunlit areas that facilitate basking opportunities and shaded areas presented by ash tree (Fraxinus excelsior) and oak (Quercus robur), the latter tree being in greater proportion. The urban garden habitat (area $1197 \mathrm{~m}^{2}$ ) is also low cost (sensu Huey \& Slatkin 1976) 
but had more open areas and slightly less cover than the hedgerow: approximate areas of cover were $40 \%$ in garden habitat and in excess of $90 \%$ in the hedgerow (see Figs. $1 \mathrm{~A}$ and $1 \mathrm{~B}$ ).

Lizard sampling. Sampling was approximately even across seasons, allowing for inclement weather. In the hedgerow habitat sampling was confined from morning (first lizards seen around 0900hrs) to midday due to the habitat being in shade after this period. In the garden habitat, which was south facing and in sun most of the day sampling was also from around $15 \mathrm{hrs}$ to $1800 \mathrm{hrs}$. Sampling frequency ranged from 32.5 to 30 hours from April to October and November in the garden population but fewer during March and December (7.35-15 hrs respectively). Data were collected by systematically slowly walking along the hedgerow and garden area and photographing any lizards detected. A total of 631 photographs $(L$. bilineata $n=258$, $P$. muralis $n=373$ ) were taken in the hedgerow. When possible when sighted several photographs of each or groups of lizards were usually taken, but only one for each sighting used which was the best quality example. Using one photograph per sampling session also minimized the risk of pseudoreplication. Sampling effort was 5-6 days each week for around 45-60 minutes daily, usually from around $0830 \mathrm{hrs}$ but up to around $1300 \mathrm{hrs}$ in the hedgerow but occasionally until evening in the garden population, especially when the weather was cloudy. Photographs enabled identification of each individual lizard (Welbourne 2020) but only one per day was included in the analysis, giving a total of 39 for $L$. bilineata and 107 for $P$. muralis in the hedgerow, and 361 photographs of $P$. muralis out of a total of 844 taken in the garden. Basking sites are defined those observed used by lizards. For example shaded areas where lizards might be seen were not by definition basking sites. Additionally lizards crossed areas of open ground when moving from one location to another but these were not basking sites and hence the substrates types the moved across were not included in the analysis.

Estimating substratum availability. Available substratum proportions were estimated by simple measurement using a tape measure to calculate surface area of all potential basking sites. Potential basking sites were defined as those sites where at least one basking lizard was observed on at least one occasion. Only the curved surface areas of fallen branches or tree trunks exposed to sunshine were measured since these were the areas where lizards basked. The irregular surfaces of stones or open ground patches when in sunshine were calculated as near possible to an estimated $\pm 5 \%$ error.

\section{Statistical analysis}

To examine whether lizards non-randomly used different substrates for basking, we compared the substratum use with substratum availability. This required constructing models that produced patterns of expected probabilities (Gotelli and Ellison 2004). The proportions of various substratum types considered available as basking locations were calculated and used as the random model. This random model was then evaluated against the frequency that lizards actually used these habitats. The assumption was that if substratum use was proportional to its availability, then selection would be considered random and non-selective; deviations from the null model were instead an indication that substratum selection was non-random. In Table 1, a value of 1 indicates that observed substratum use is random and hence proportional with its availability. The test used was the Kolmogorov-Smirnov Goodness of Fit test $\left(D_{\max }\right)$ 
that has value in that it is an exact and distribution-free test, and hence robust and not sensitive to cell counts. In this study the test hypothesis is $\mathrm{H}_{0}: P=P_{0}, \mathrm{H}_{1}, P \neq P o$, where $P$ is the observed distribution of substratum use and $\mathrm{P}_{\mathrm{O}}$ the distribution of available substrates.

Table 1

A. Results of the Kolmogorov-Smirnov one-sample $D_{\max }$ tests of observed substratum use for basking tested against expected frequencies under a null hypothesis of substratum availability in the hedgerow. Values of 1 indicate substratum use in agreement with availability, negative values less use and positive values greater use. See text for further details. No L. bilineata was observed basking on stones.

\begin{tabular}{|llllllll|}
\hline & Fallen branches & Tree & $\begin{array}{c}\text { Tree } \\
\text { stump }\end{array}$ & Stones & Soil & $\mathbf{D}_{\max }$ & P $\mathbf{n}$ \\
\hline P. muralis & 1.86 & -1.03 & 8.65 & -1.45 & -6.51 & 0.439 & $<0.01103$ \\
\hline L. bilineata & -0.73 & -5.13 & 2.92 & - & 1.08 & 0.189 & 0.1839 \\
\hline
\end{tabular}

Table 1

b. Results of the Kolmogorov-Smirnov one-sample $D_{\max }$ tests of observed substratum use for basking tested against expected frequencies under a null hypothesis of substratum type availability in the garden habitat. Ivy (Hedera) was the only plant used by lizards as a basking surface. Other details as Table $1 \mathrm{~A}$.

\begin{tabular}{|llllllll|}
\hline P. muralis & limestone & Red tiles & wood & Hedera & concrete & $\mathbf{D}_{\max }$ & P n \\
\hline Mar-June & 1.62 & 1.21 & 6.64 & -0.69 & -1.22 & 0.201 & $=0.0163$ \\
\hline July-Sept & -2.02 & 1.24 & 3.83 & 1.37 & 1.33 & 0.265 & $<0.0169$ \\
\hline Oct-Nov & -5.79 & 1.41 & 4.71 & 2.79 & -0.95 & 0.221 & $<0.01175$ \\
\hline Pooled & -5.68 & 1.33 & 4.91 & 2.01 & 1.01 & 0.227 & $<0.01307$ \\
\hline
\end{tabular}


Table 2

Communal basking composition of individuals in $P$. muralis at both study localities. Additional communal basking of one $L . b$ and $P . m$ sharing fallen branches as basking substratum was observed on two occasions.

\begin{tabular}{|c|c|c|c|c|c|c|c|}
\hline & $\begin{array}{l}1 \text { Male, } \\
1 \\
\text { female }\end{array}$ & $\begin{array}{l}1 \text { male } \\
2 \\
\text { females }\end{array}$ & $\begin{array}{l}2 \\
\text { females }\end{array}$ & $\begin{array}{l}1 \text { male } \\
1 \\
\text { subadult }\end{array}$ & $\begin{array}{l}1 \text { female } \\
1 \\
\text { subadult }\end{array}$ & $\begin{array}{l}1 \text { male } \\
1 \text { female } \\
1 \text { subadult }\end{array}$ & $\begin{array}{l}2 \\
\text { subadults }\end{array}$ \\
\hline Hedge & 2 & 2 & 0 & 0 & 0 & 0 & 0 \\
\hline Garden & 16 & 4 & 7 & 2 & 0 & 1 & 3 \\
\hline
\end{tabular}

Affiliations

Institute for Development, Ecology, Conservation and Cooperation, Via G. Tomasi di5 Lampedusa 33, I-00144 Rome, Italy

The expected probabilities were derived from the summed substratum availability after conversion to decimal fractions. The Kolmogorov-Smirnov test requires that $\sum n=1$, where $n$ is the decimal proportions. The expected proportions for the garden habitat were:- Limestone (walls), 0.526; red tiles, 0.0525; wood, 0.0454 ; concrete, 0.349 .

In the hedgerow expected proportions were:-

Tree stump, 0.027; fallen tree branches, 0.270 ; open areas with no vegetation, 0.487 ; Tree bark, 0.135 ; limestones, 0.081 .

In a test for monthly frequency of communal basking in $P$. muralis (frequency of groups of lizards basking together) in the garden population, the Kolmogorov-Smirnov Goodness of Fit Test was used. The null hypothesis is monthly equality of communal basking. This was derived from

Expected $=1 / N_{1} * N_{2}$

where $N_{1}$ is number of months and $N_{2}$ the total sample size. This gave an expected value of 4.875 groups of lizards (up to three) in each cell (month).

The tests were set at the 95\% interval with deviation from the expected probabilities indicated if the $95 \%$ intervals were attained or exceeded. Tests for independent proportions were made using $z$-tests to test for seasonal differences comparing basking on surface types which had wood surfaces, trees, fallen branches and a tree stump versus areas composed of bare soil or stones and concrete.

\section{Results}

\section{Hedgerow}


Basking P. muralis were observed on fallen branches (50.4\% of $n=107$ observations), tree stump (23.4\%), trees (13.1\%), bare soil (7.7\%) and stones (5.6\%). Basking in $L$ bilineata was greater on bare soil substrates (52.6\% of $n=38$ observations), fallen logs (36.8\%), tree stump $(7.98 \%)$ and tree trunks $(2.6 \%)$ (see examples in Fig. 2A \& 2B). However, in terms of availability there were inter-specific differences in basking substratum use with $P$. muralis showing significantly different selection from the null model of expected probabilities (Fig. 3). In contrast L. bilineata showed no significant departure of substratum use from substratum availability $\left(D_{\max }=0.189, P=0.18\right)$. Table 1 a shows the full results of the $D_{\text {max }}$ Goodness of Fit tests.

Seasonality tests. Sample sizes in the hedgerow constrained the seasonality tests to April to the end of June and from July to October. The results showed that $P$. muralis spent a significantly greater time basking on wood surfaces (94\%, total $n=44$ compared to $L$. bilineata $(68.2 \%$, total $n=22)$ during AprilJune $(z=2.47, \mathrm{P}=0.007)$ and also during July - October (P. muralis, 79.7\% (total $n=59)$ vs L. bilineata, 23.5\% (total $n=17$ ); $z=4.76, \mathrm{P}<0.001$ ). However, both $P$. muralis and $L$. bilineata increased time spent on bare soil/stones during July - October (L. bilineata 31.8 to $76.5 \%$; P. muralis 6 to $20.3 \%$ ) (Fig. 4).

\section{Garden habitat}

The $P$. muralis garden population (total $n=361$ ) was seen in greater numbers on limestone walls $(52.6 \%)$ and concrete based surfaces (34.9\%) than other substrates. However, in respect to availability there was a strong preference for wood surfaces but this was much reduced during the hotter summer (Fig. 5).

Secondary selection based on availability was for red tiles, which was also greater than expected during all periods of the active year. The full results for this population are shown in Table $1 \mathrm{~b}$.

Seasonality tests Tests for seasonal differences in proportions between substratum use in $P$. muralis showed statistically greater use of wood in March - June (30.2\%) compared to July - September (17.4\%; $z=1.72, \mathrm{P}=0.04)$ but not compared to October-November $(21.43 \% ; z=1.32, \mathrm{P}=0.09)$. Wood substrate selection was also significantly greater during October - November compared to July - September $(z=$ $1.87, \mathrm{P}=0.03)$. These results indicate wood substrates for basking was in greater use during the cooler months compared to mid-summer months.

\section{Communal basking}

Communal basking was observed in both species but in significantly greater frequency in $P$. muralis (garden, 9.4\%; hedgerow, 4.7\%) but these frequencies were not significantly different $(z=1.83, P=0.07)$. Therefore the data for $P$. muralis were pooled and indicated greater communal basking in $P$. muralis ( pooled data $=8.33 \%$, ) compared with L. bilineata $(2.56 \% ; z=2.005, \mathrm{P}=0.04)$. The $D_{\max }$ Goodness of Fit test against equality of months for $P$. muralis communal basking in the garden habitat indicated a significant departure from equality $(D=0.366, \mathrm{P}<0.01)$ occurring in greater frequencies during April $(\mathrm{x}$ 2.05), October (x 1.64) and November (x 3.28). Figure 6 shows a histogram of frequencies at both study areas. 


\section{Discussion}

Our study has shown strong preference for wood as a basking substratum in both $P$. muralis and $L$. bilineata, which supports our prediction (1) and is in good agreement with the earlier findings of Hailey (1982) in his study of the cold adapted Z. vivipara. Careful thermoregulation in terms of the benefits of selecting wood-based substrates will be economical when such sites are in relatively close proximity and will be more likely to be achieved in low cost habitats both in terms of thermal opportunities and predation risk (e.g. Huey 1991). Increased thermoregulations in low cost habitats enable body temperatures to more closely reach optimum levels (e.g. Huey and Slatkin 1976) indicating the present day importance of, not only suburban gardens, but hedgerow systems in fragmented landscapes. Predators were rarely seen in both our study sites $(n=5)$ but various sized individuals of the saurophagus snake (Hierophis viridiflavus) were the most frequent. We observed both hatchling and subadult $H$. viridiflavus, both categories preying actively upon P. muralis (e.g., Rugiero and Luiselli 1995; Capizzi et al. 2008), and given the secretive behaviour in snakes they may actually be more frequent than actually seen. The grass snake Natrix helvetica was also seen on four occasions (two in each study area) during the study period but these snakes are essentially predators of amphibians rather than lizards (e.g., Luiselli et al. 2005). Lacertid lizards are able to detect snake presence using chemical cues (Van Damme and Quick, 2001; but see Cerini et al. 2020 for different results) and therefore it is conceivable that when $H$. viridiflavus are present the lizards do indeed shift to more safe habitats (Meek 2014), as we felt also happened at our study sites.

Our observation of lower use of wood based surfaces in $P$. muralis during the hotter summer months supports our prediction based on Hailey's (1982) results. For example, fallen log use declined as summer progressed into autumn in both species ( $P$. muralis 94 to $79.7 \%$ versus L. bilineata 68.2 to $23.5 \%$ ) with basking on open ground increasing over the same time period (P. muralis 6 to $20.3 \%$ versus L. bilineata 31.8 to $76.5 \%$ ). These changes likely reflect the warmer summer environment but differences between species might reflect different life styles or longer distance movement in L. bilineata.

Non-significant (random) substratum selection at a finer level in L. bilineata was perhaps unexpected but the advantages of reduced basking duration offered by wood was observed when data for wood based materials were pooled and compared seasonally to non-wood (stones, bare soil). Increased movement onto bare soil substrates during the latter part of the year in this species, which is in agreement with a study of L. bilineata in northern Italy (Luppi et al. 2020), suggests that other factors were involved in substratum/microhabitat selection, perhaps enhanced prey and predator detection. Podarcis muralis also showed a similar but less evident trend (Fig. 3). For example, P. muralis selected substrates to scan horizontal surfaces for potential prey species (Avery et al 1993; Avery 1994). Fallen branches and tree stumps in our study may serve this purpose and also enable enhanced detection of potential predators. Lacerta bilineata is well known for intra-specific aggression with minimal (or rare) communal basking (Beebee and Griffiths, 2000), including cannibalistic acts (Angelici et al., 1997; Rugiero et al., 2021). This interference competition may constrain some individuals in the population to avoid accessing optimum basking sites by the presence of other lizards, especially large males. For example, a lizard can increase 
net energy gain from careful thermoregulation if it can exclude potential competitors from optimum basking sites (e.g. Huey and Slatkin 1979). Furthermore such sites may reduce shuttling, which increases risk of predation and optimizes detection of insect prey and the approach of predators. Greater home ranges in $L$. bilineata may influence familiarity with prime basking locations. Individually identified $P$. muralis, for example, were present in all months of the active year in both habitats, which might enable greater habitat familiarity.

In a study of $L$.bilineata in Germany morning basking was observed on $f *-$ heat $\in$ gstructures such as moss or compact layers of grass and tracked lizards sometimes moved over long distances (up to $205 \mathrm{~m}$ within an hour) when movements were rapid suggesting that the lizards knew the area and exactly where to go (Sound and Veith 2000). This might also suggest that the lizards were in fact familiar with optimum basking patches. Males also prevented other males entering their territory (Sound and Veith 2000), which supports our observations of low communal basking frequency. Interaction with $P$. muralis was rarely observed except on two occasions when two individuals shared basking sites (both on fallen branches). Other studies have shown niche segregation between sympatric $L$. agilis and $L$. viridis (a species that is closely related to L. bilineata; see Böhme et al., 2007) based on fine scale habitat patch use, with $L$. agilis operating in open spaces and L. viridis bushy areas, despite generally similar daily activity patterns (Heltai et al. 2015).

The skewed presence of communal basking occurrence in the garden population of $P$. muralis was likely due to (i) emergence and mating behaviour in spring and (ii) individuals clustering around winter den areas in autumn (Fig. 5 and Table 3). The latter may constrain microhabitat/substratum selection during November, when the colder days increase risk of movement around the environment. Communal basking may also facilitate early female - male contact for reproduction in Spring. One group of seven lizards (including just one male) used the same den for hibernation during late November.

The results of the present study are of additional interest in respect of the ability of both species to colonize areas outside their natural range, for example USA and more northerly areas of Europe, but especially the cooler climate in the south of England where extra demands on thermal ecology are present. For instance, it might be expected that optimum patch selection would also operate in these newer cooler habitats given the higher selected body temperatures of $P$. muralis and L. bilineata in comparison to native $Z$. vivipara (Avery 1978). An example of the adaptive capability of $P$. muralis has been shown by non-native females in the south of England where female reproductive investment was shifted into the first seasons clutch which differed from females in their natural (Italy) range (MacGregor et al. 2017).

\section{Declarations}

Acknowledgements. Comments by Dr Roger Avery greatly improved the submitted manuscript.

\section{Funding - none}


Conflicts of interest - none

Ethics approval - not applicable

Consent for publication - Both authors read and approved the final manuscript, and accepted to be coauthors in the published paper.

Availability of data and materials - Data will be available by the first author (RM) on request

Competing interests The authors declare no competing interests

Funding - none received

Author contributions - RM and LL initiated the study and wrote the manuscript. RM carried out the field work and data analysis. Both authors agreed on the final submitted version of the manuscript.

\section{References}

1. Allan GM, Prelypchan C.J. Gregory P.T. (2006) Population profile of an introduced species, the common wall lizard (Podarcis muralis), on Vancouver Island, Canada. Can J Zool 84, 51-57

2. Angelici FM, Luiselli L, Rugiero L. (1997) Food habits of the green lizard, Lacerta bilineata, in central Italy and a reliability test of faecal pellet analysis. Ital J Zool 64: 267-272.

3. Audsley BW, Bock, CE Jones ZF, Bock, JE, Smith HM (2006). Lizard abundance in an exurban southwestern savanna, and the possible importance of roadrunner predation. Am Midl Nat 155:395401.

4. Avery RA (1978). Activity patterns, thermoregulation and food consumption in two sympatric lizard species (Podarcis muralis and P. sicula) from Central Italy. J Animal Ecol 47: 143-158

5. Avery RA 1979. Lizards, a Study in Thermoregulation (The Institute of Biology's studies in Biology no. 109).

6. Avery RA (1994). The survey posture in wall lizards, Podarcis muralis. Herp J 4: $132-135$.

7. Avery R A, Basker A, Corti C. (1993). 'Scan' behaviour in Podarcis muralis: the use of vantage points by an actively-foraging lizard. Amphibia-Reptilia 14:247-259

8. Barbault R, \& Mou Y. P. (1986). Regime alimentaire d'une population de lezard des murailles, Podarcis muralis (Laurent, 1768) dans le Sud-Ouest de la France. Amphibia-Reptilia 7: 171-180.

9. Basson C. H. Levy O. Angilletta Jr M J, Clusella Trullas S. (2017). Lizards paid a greater opportunity cost to thermoregulate in a less heterogeneous environment. Funct Ecol 31: 856-865.

10. Bauwens D, Garland JR, Castilla AM, Van Damme R. (1995) Evolution of sprint speed in lacertid lizards: morphological, physiological, and behavioral covariation. Evolution 49:848-863.

11. Bauwens D, Hertz PE, Castilla AM (1996). Thermoregulation in a lacertid lizard: the relative contribution of distinct behavioral mechanisms. Ecology 77:1818-1830. 
12. Böhm M, Collen B, Baillie JEM, Bowles P, Chanson J, Cox N, Hammerson G, Hoffmann M, Livingstone SR, Ram M, et al, 2013. The conservation status of the world's reptiles. Biol. Cons. 157: 372-385. https://doi.org/10.1016/j.biocon.2012.07.015

13. Böhme MU, Kotenko T, Džukić G, Ljubisavljević K, Tzankov N, \& Berendonk T U (2007). Phylogeography and cryptic variation within the Lacerta viridis complex (Lacertidae, Reptilia). Zool Scr 36: 119-131.

14. Capizzi D, Capula M, Rugiero L, Luiselli L. (2008). Dietary patterns of two sympatric Mediterranean snakes (Hierophis viridiflavus and Zamenis longissimus) along a gradient of habitat alteration. Herp J 18: 141-146.

15. Carrascal LM, López P, Martín J, \& Salvador A. (1992). Basking and antipredator behaviour in a high altitude lizard: implications of heat exchange rate. Ethology 92: 143-154.

16. Castilla AM, Van Damme R. Bauwens D. (1999). Field body temperatures, mechanisms of thermoregulation and evolution of thermal characteristics in lacertid lizards. Nat Croat 8: 253-274, 1999

17. Cerini F, Mattei G, Luiselli L, Vignoli L. (2020). Do lizards (Podarcis siculus) react to whip snake (Hierophis viridiflavus) scents? A comparative test on odour stimuli recognition. Behaviour: DOI:10.1163/1568539X-bja10003.

18. Chakravarti L, Roy, (1967). Handbook of Methods of Applied Statistics,Vol I, John Wiley and Sons, pp. 392-394.

19. Corti C, Capula M, Luiselli L, Razzetti E, Sindaco R. (2011). Reptilia. In Fauna d'Italia, Calderini editore, Bologna.

20. Doherty TS, Balouch S, Bell K, Burns T J, Feldman A, Fist C, Garvey TF, Jessop TS, Meiri S, Driscoll DA. (2020). Reptile responses to anthropogenic habitat modification: A global meta-analysis. Global Ecol Beogr 29: 1265-1279. https://doi.org/10.1111/geb.13091

21. Dustin JW, Andrew W. Claridge DJP, Ford F. (2020). Camera-traps are a cost-effective method for surveying terrestrial squamates: A comparison with artificial refuges and pitfall traps, PLOS ONE 10.1371/journal.pone.0226913, 15, 1: (e0226913), (2020).

22. Germaines SS, Wakeling BF. (2001). Lizard species distributions and habitat occupation along an urban gradient in Tucson, Arizona, USA. Biol Conserv 97:229-237.

23. Gotelli NJ, Ellison AM. (2004). A Primer of Ecological Statistics. 510 pp. Sinauer Associates, Sunderland, USA

24. Hailey A. (1982). Choice of substrate and heating rate in Lacerta vivipara. Brit J Herp 6: 207-213.

25. Heltai B, Sály P. Kovác, D, Kiss I. (2015): Niche segregation of sand lizard (Lacerta agilis) and green lizard (Lacerta viridis) in an urban semi-natural habitat. Amphibia-Reptilia36: 389-399.

DOI:10.1163/15685381-00003018

26. Herczeg G, Herrero A, Saarikivi J, Gonda A, Jäntti M. Merilä J. (2008). Experimental support for the cost-benefit model of lizard thermoregulation: the effects of predation risk and food supply. Oecologia: 155: 1-10. 
27. Heym A, Deichsel G, Hochkirch A, Veith M \& Schulte U. (2013). Do introduced wall lizards (Podarcis muralis) cause niche shifts in a native sand lizard (Lacerta agilis) population? A case study from south-western Germany. Salamandra 49: 97 - 104

28. Huey, R. B. 1991 Physiological consequences of habitat selection. Am. Nat. 137: S91-S115. (doi:10.1086/285141)

29. Huey RB \& Slatkin M. 1976 Costs and benefits of lizard thermoregulation. Q Rev Biol 51: 363-384. (doi:10.1086/409470)

30. Jellinek S, Driscoll DA, Kirkpatrick J.B. (2000). Environmental and vegetation variables have a greater influence than habitat fragmentation in structuring lizard communities in remnant urban bushland. Austral Ecol 29:294-304.

31. Keinath DA, Doak DF, Hodges KE, Prugh L.R., Fagan W, Sercercioglu CH, Buchart SHM Kaufman. (2016). A global analysis of traits predicting species sensitivity to habitat fragmentation. Global Ecol and Biogeogr26: 115 - 127.

32. Luiselli L, Capizzi D. (1997). Influences of area, isolation and habitat features on distribution of snakes in Mediterranean fragmented woodlands. Biodiv Conserv 6: 1339-1351.

33. Luiselli L, Filippi E, Capula M. (2005). Geographic variation in diet composition of the grass snake (Natrix natrix) along the mainland and an island of Italy: the effects of habitat type and interference with potential competitors. Herp J 15: 221-230.

34. MacGregor HEA, While GM, Uller T. (2017). Comparison of reproductive investment in native and nonnative populations of common wall lizards reveals sex differences in adaptive potential. Oikos 126: 1564-1574, 2017 doi: 10.1111/oik.03984

35. Massimiliano Luppi M, Augusto Gentilli A \& Bogliani. G. (2020). Microhabitat selection of the Western green lizard Lacerta bilineata. Atti Soc it Sci. nat Museo civ Stor nat Milano7 (2): 3-10,DOI: $10.4081 /$ nhs. 2020.451

36. Meek R. (2014a). Reptile dispersal from a hibernaculum in an agricultural landscape in Western France. Herp Bull 127: 17-21.

37. Meek R. (2014b). Temporal distributions, habitat associations and behaviour of the green lizard (Lacerta bilineata) and wall lizard (Podarcis muralis) on roads in a fragmented landscape in Western France. Acta Herpeto/9: 179 - 186

38. Mole SRC. (2010). Changes in relative abundance of the western green lizard Lacerta bilineata and the common wall lizard Podarcis muralis introduced onto Boscombe Cliffs, Dorset, UK. Herp Bull 114: $24-29$.

39. Rugiero, L \& Luiselli, L. (1995). Food habits of the snake Coluber viridiflavus in relation to prey availability. Amphibia-Reptilia: 16: 407-411.

40. Rugiero L, Vignoli L, Luiselli L \& Meek R. (2018).pSpring basking by Vipera aspis: Observations from Italy and France on the displacement distances of basking vipers from their hibernacula. Herp Bul/145: 22 - 27. Lacerta viridis. Oecologia (5:125-131 
41. Saint Girons H. (1996). Structure et evolution d $u \neq$ petitepopationdeViperaas $\pi s(L)$ dansu $\neq$ regiondeboca $\geq$ delouest de la France. Terre et La Vie-Revue D. Ecolologie Appliquee 51: 223 - 241.

42. Sound $P$, Veith M. (2000).Weather effects on intrahabitat movements of the western green lizard, Lacerta bilineata (Daudin, 1802), at its northern distribution range border: a radio-tracking study. Can J Zool 78: 1831-1839

43. Tait CJ, Daniels CB, Hill RS. (2005). Changes in species assemblages within the Adelaide metropolitan area, Australia, 1836-2002. Ecol Appl 15:346-359.

44. Tinkle DW, Ballinger RE, (1972). Sceloporus undulatus. A study of the intra-specific comparative demography of a lizard. Ecology 53:570-584.

45. Van Damme R, Quick K. (2001): Use of predator chemical cues by three species of Lacertid lizards (Lacerta bedriagae, Podarcis tiliquerta and Podarcis sicula). J Herpetol 35: 27-36.

46. Verwaijen D, Van Damme R. (2008): Foraging mode and its flexibility in Lacertid lizards from Europe. J Herpetol. 42: 124-133.

47. Vignoli L, Mocaer I, Luiselli L, Bologna MA (2009). Can a large metropolis sustain complex herpetofauna communities? An analysis of the suitability of green space fragments in Rome. Anim Conserv 12: 456-466.

48. Walker JM, Cordes JE, Taylor, HL (1996). Extirpation of the parthenogenetic lizard Cnemidophorus tesselatus from historically signifcant sites in Pueblo County, Colorado. Herp Rev27: 16-17.

49. Yang H, Doherty TS, Jessop (2020), How influential are squamate reptile traits in explaining population responses to environmental disturbances? Wildl Res 10.1071/WR19064, 47: 249.

\section{Figures}

\section{Figure 1}

Google Earth map showing hedgerow with agriculture land either side (A). Insert is sampling area. Examples of basking areas used by P. muralis. A shows limestone wall and B deadwood and raised bed created from limestones.

层

\section{Figure 2}

(A) Examples of $L$. bilineata basking on various surfaces. Fig $2 A$ shows $L$. bilineata male basking on tree stump, $B$ female on fallen branch, $C$ female on bark of tree trunk and $D$ female on bare soil. (B) Figure 2B. Examples of $P$. muralis basking; $A, B$ and $C$ show lizards in the hedgerow with $A$ male basking on tree stump, $B$ female on bare soil and $C$ male (right) and female communal basking on fallen branch. 
Photographs D, E and $F$ show lizards in the garden habitat $D$ male on wood, $E$ three lizards communal basking on red tile (male left, female right) and female on concrete and $\mathrm{F}$ communal basking with male (top) on concrete and female on limestone.

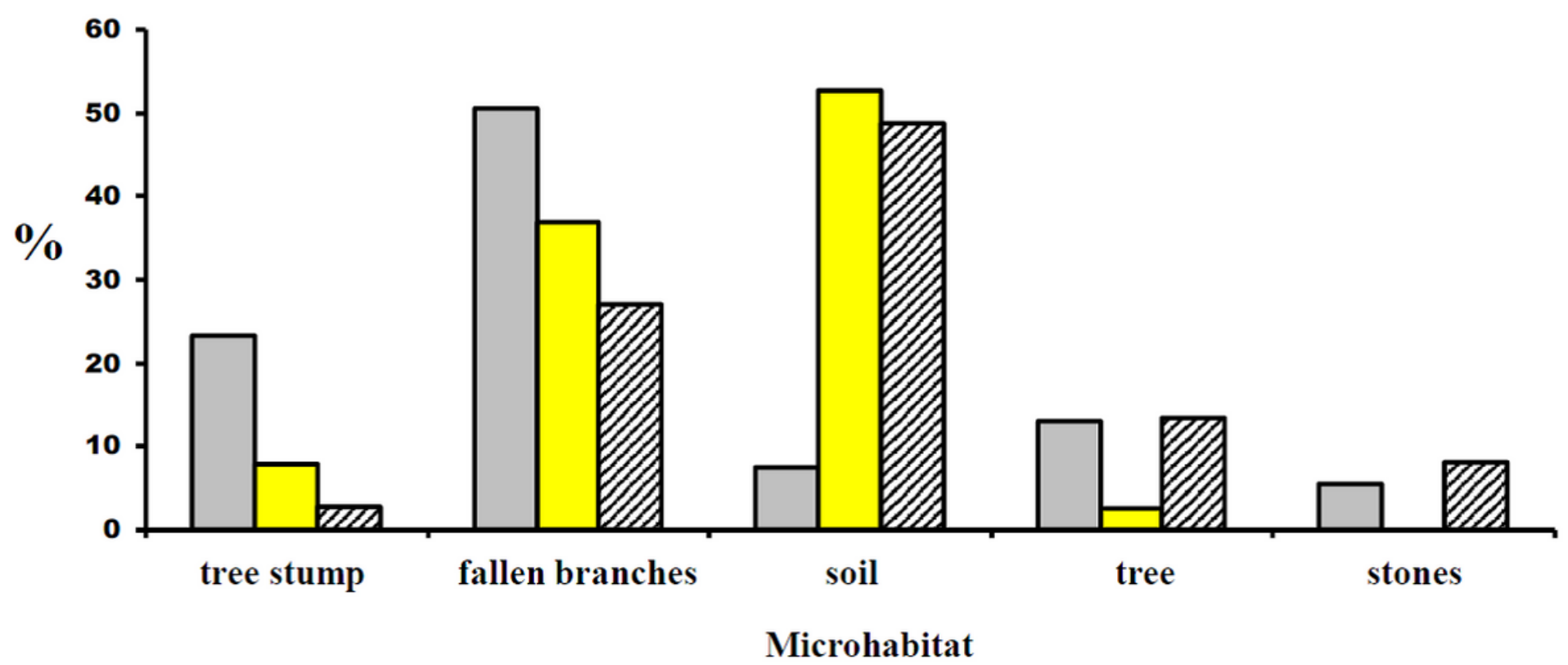

Figure 3

Observed versus expected substratum use in the hedgerow indicating selection in P. muralis but nonsignificance in L. bilineata. Grey histograms are P. muralis, and yellow L. bilineata. Cross hatched are the expected probabilities based on basking area availability.

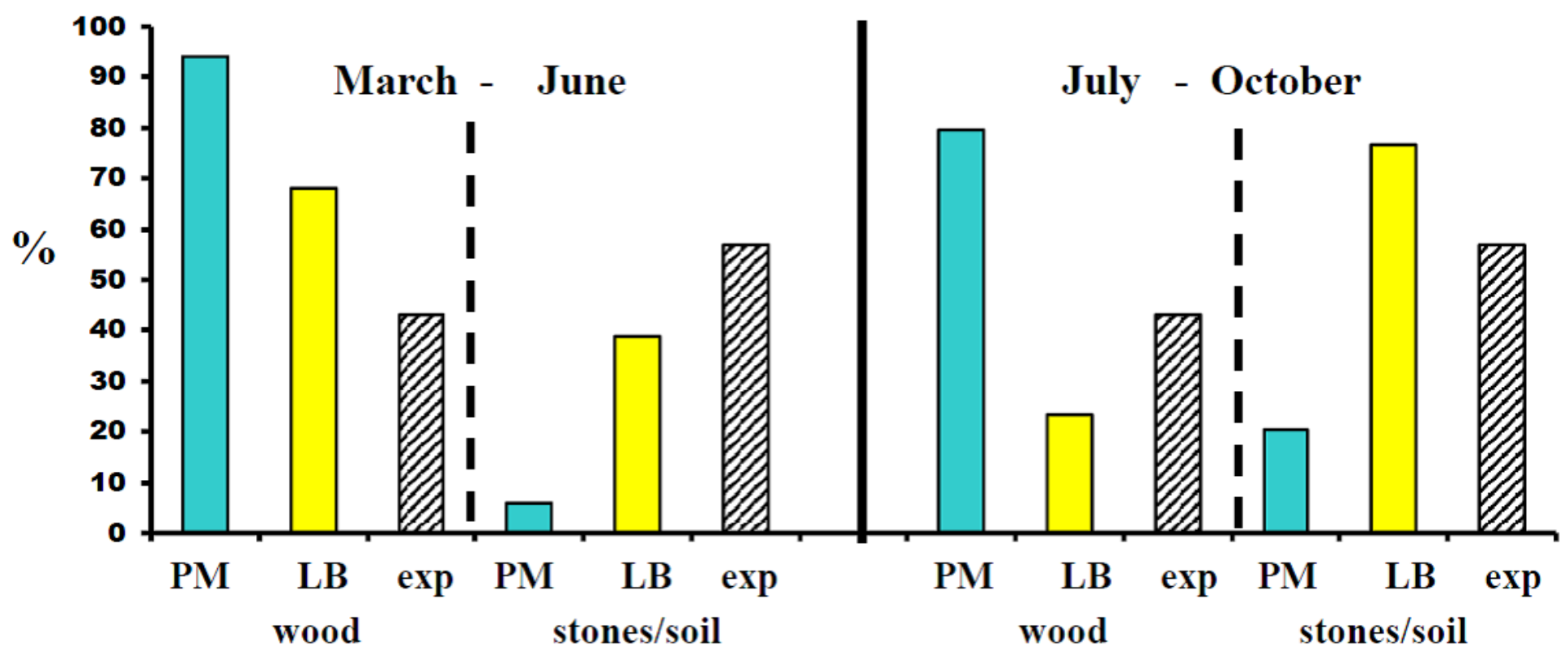

Figure 4

Seasonal substratum type selection when types of surface are pooled, for instance wood consists of trees, fallen branches and tree stump data, soil is open bare soil patches with little or no vegetation cover 
or stones.

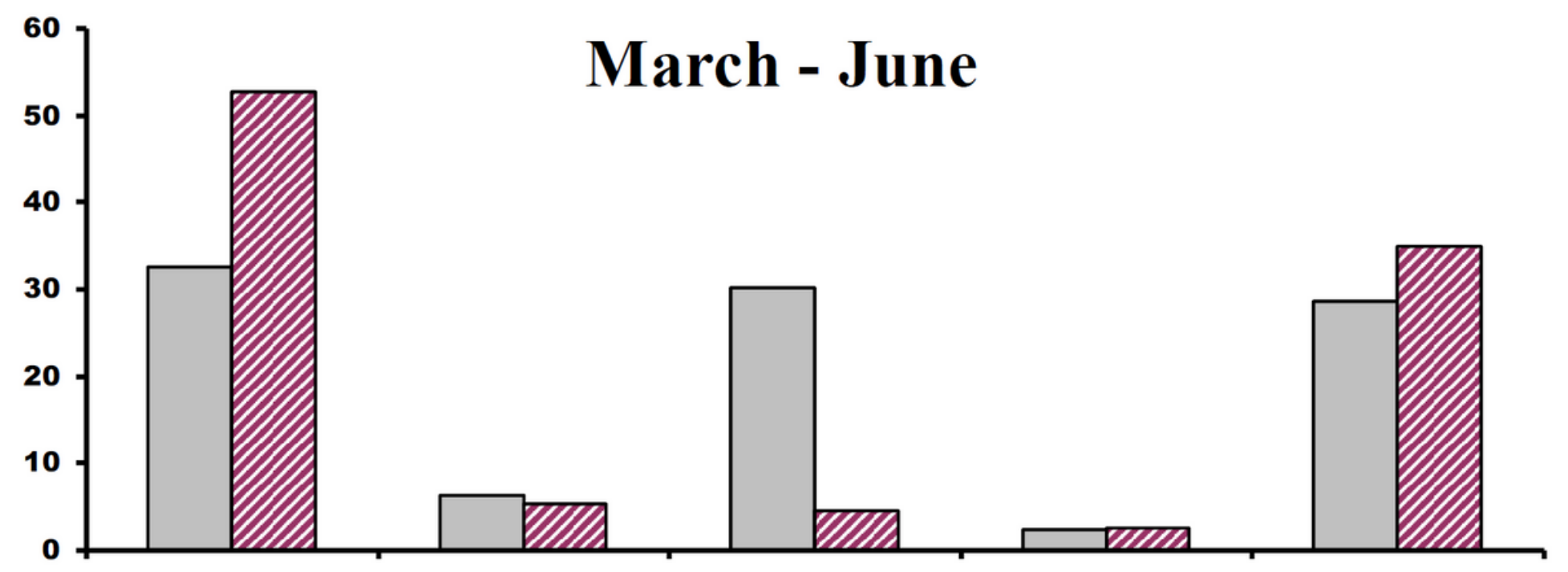

Figure 5

Observed and expected frequencies of substratum type selection for basking P. muralis in the garden population during 3 periods of the active year. Crosshatched areas indicated expected probabilities based on basking area availability.

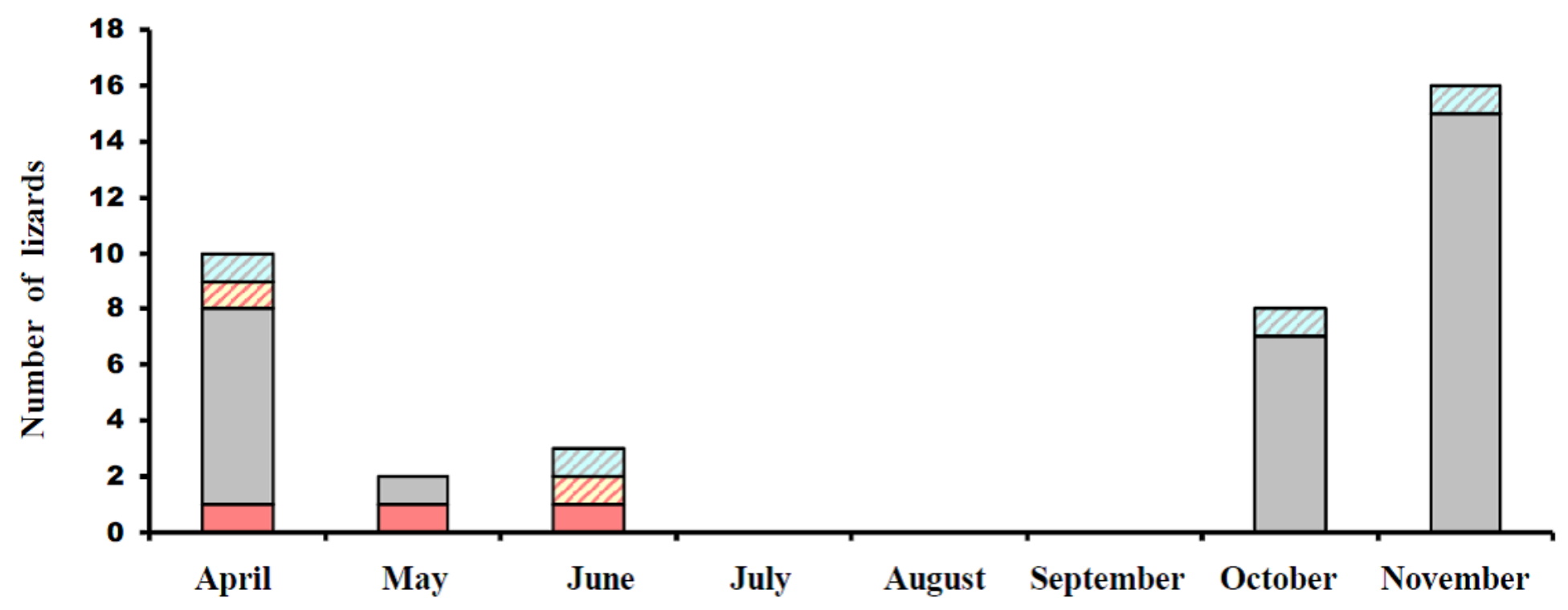

Figure 6

Communal basking in P. muralis. Green indicates two lizards together and cross-hatched green areas represent three lizards in the group in the hedgerow. Garden population is shown as grey when there were two lizards in the group and cross-hatched grey when three lizards were in a group. Examples are show in Figure 2. 